\title{
The Opposing Viewpoints of Slavery in Nineteenth-Century \\ American Poetry: An Anthology
}

- Madison Yeary, Indiana University

\section{Abstract:}

This anthology delves into a critical time period in American history, illustrates various arguments for and against slavery in the nineteenth century, and showcases some of the most powerful and insightful poems of the era.
KeY WORDS:

Freedom, Slavery, Abolition, Master, Faith

\section{Table of Contents}

Introduction

Henry Wadsworth Longfellow 38

"The Witnesses"

Oliver Wendell Holmes Sr.

"The Flower of Liberty"

John Pierpont

"The Fugitive Slave's Apostrophe to the North Star"

"The Slaveholder's Address to the North Star"

William Gilmore Simms

"Billows"

"Yes, Lone Were My Bosom"

Conclusion

Works Cited 


\section{INTRODUCTION}

On April 12, 1861, America entered what would become the deadliest war in its recorded history. Fought only on American soil, the Civil War nearly split the once "United" States and caused approximately six hundred twenty-five thousand casualties. Due to such political and environmental polarities between the quickly industrializing North and the slave owning agricultural South, tensions quickly rose. In 1860, just after the election of abolitionist president Abraham Lincoln, the rebel states began their secession. As the war continued and more lives were lost, an exponential increase of cultural figures, such as writers and professors, immersed themselves in politics and avidly supported their side, resulting in the rise of influential literature. Long after the abolishment of slavery and the end of the war on April 9, 1865, books and poems were still published on the opinions prompting the bloodshed. The contradictory attitudes between the loyal North and rebel South, specifically concerning the issue of slavery, ineludibly manifested themselves through nineteenth-century American poetry.

This anthology contains six annotated poems exemplifying specific differences between the Northern and Southern stance on slavery. Arranged according to their respective views regarding the political policy of slavery, the first three pieces include only antislavery poems written by northern abolitionists. These poems particularly reflect the role played by religion and spiritualism in the abolitionist stance against slavery. In contrast, the latter half of the anthology's poems demonstrates the South's overpowering ego and sense of entitlement, which resulted in their full support for the use of slaves.

The first poem in this anthology - "The Witnesses" - was written by Fireside Poet Henry Wadsworth Longfellow in 1842 . This piece depicts the inhumanity of the pre-war slave trade by divulging the harsh reality of slavery's oppression, which resulted in the loss of so many lives.

Another Fireside Poet, Oliver Wendell Holmes Sr. in 1861, wrote the anthology's next poem, titled "The Flower of Liberty". This poem epitomizes the symbolic patriotism of the American Flag, which the Northern Soldiers used for motivation to keep fighting for their cause in such a violent and austere civil war.

"The last two anti-slavery poems in this anthology that symbolize the Northern cause were both written by John Pierpont in 1839: the first is titled "The Fugitive Slave's Apostrophe To The North Star" and the second "The Slaveholder's Address To The North Star." The first is written from the point of view of a runaway slave and depicts his journey strictly at night, guided by the light of the North Star on the Underground Railroad. Pierpont wrote the second from the point of view of a harsh and ignorant slave owner. In this poem, a slave owner mocks the same North Star followed so desperately by the fugitive slave. Opening with the lines "Star of the North, thou art not bigger / / Than is the diamond in my ring;" Pierpont flawlessly exemplifies the arrogance held by many southern slave owners. The people south of the Dixie-line defended their use of slaves by claiming that African-Americans were nothing more than mere savages who bettered their lives when becoming slaves because it gave them a purpose for living. In the anthology, then, Pierpont's second poem acts as a bridge into the second section, which represents actual pro-slavery poetry."

Southern historian and pro-slavery advocate William Gilmore Simms wrote "Billows," the first poem included in the set of pro-slavery pieces, in 1832. This piece claims with the same unashamed pride as the others that the masters of slaves in the South deserved their slaves just because of the color of their skin.

The anthology's sixth and final poem, titled "Yes, Lone Were My Bosom," was published in 1853 by the same author as the preceding poem - William Gilmore Simms. Yet again written from the viewpoint of a Southern slaveholder, this poem egotistically expresses Simms's rationale of and justification for slavery as a positive practice. 
As clearly seen in the poetry of the time, there were dramatic differences between the nature and politics of a young, split America. The loyalist North supported the abolition of slavery, while the rebel South fought till its death in an attempt to keep it. Just four short years, from 1861-1865, caused both the history and literature of the United States to be changed indefinitely.

\section{HeNRY WADSWORTH LONGFELLOW (1807-1882)}

Merely three years after his birth in Portland, Maine on February 7, 1807, legendary poet Henry Wadsworth Longfellow began his formal education comparatively and notably young. Nevertheless, because of his early start, Longfellow enrolled at Bowdoin College by the impressive age of fifteen and subsequently taught modern languages at Harvard. Distinguished by his understanding that "what a writer asks of his reader is not so much to like as to listen" (Wagenknect, Henry Wadsworth Longfellow), Longfellow's poetry revolutionized American culture and thrust him into one of the five figurehead positions of the renowned Fireside Poets. Acclaimed pieces such as "Paul Revere's Ride" and "Songs of Hiawatha" inspired writers and composers alike; his poetry flourished and could be heard everywhere from parlors to civic ceremonies, and anywhere in between. However, among his life's praise and prestige came no shortage of undeserved anguish and despair. In his poem "Resignation," Longfellow recounts the feelings and ideals that held him together through those "severe afflictions" caused by the death of his daughter Fanny in 1848. Shortly after Fanny's death, Longfellow's wife, Frances, was sealing an envelope with hot wax when her dress caught fire. Although Longfellow himself eventually snuffed it out, severe burns had already covered her body and resulted in her death on the morning of July 10, 1861. During his courtship of Frances, however, Longfellow publicly solidified himself as an abolitionist when his collection, Poems on Slavery, was published in 1842. His poem, “The Witnesses," found in this collection, describes the undeniable and horrific consequences of the American slave trade.

"The Witnesses"

In Ocean's wide domains,

Half buried in the sands,

Lie skeletons in chains,

With shackled feet and hands.

Beyond the fall of dews,

Deeper than plummet lies,

Float ships, with all their crews,

No more to sink nor rise.

There the black Slave-ship swims,

Freighted with human forms,

Whose fettered, fleshless limbs

Are not the sport of storms.

These are the bones of the Slaves;

They gleam from the abyss;

They cry, from yawning waves, 
"We are the Witnesses!"

Within Earth's wide domains

Are markets for men's lives;

Their necks are galled with chains,

Their wrists are cramped with gyves. ${ }^{1}$

Dead bodies, that the kite

In deserts make its prey;

Murders, that with affright

Scare school-boys from their play!

All evil thoughts and deeds;

Anger, and lust, and pride;

The foulest, rankest weeds,

That choke Life's groaning tide!

These are the woes of the Slaves;

They glare from the abyss;

They cry, from unknown graves,

"We are the Witnesses!"

\section{Oliver Wendell Holmes Sr. (1809-1894)}

Famous for substantially more than coining the term "anesthesia," Fireside Poet Oliver Wendell Holmes, Sr. was also an American professor, physician, writer, and justice for the American Supreme Court. He was born in Cambridge, Massachusetts on August 29, 1809, where he remained until 1830. While living in Cambridge, Holmes attended Harvard College, where he graduated with a degree in classical languages and literature. Shortly following graduation, Holmes decided to continue his Harvard education and enrolled at Dane Law School in the fall 1829. After only one year, however, Holmes left his alma mater in order to study medicine and concentrate on writing. Reflecting on this decision, Holmes claimed, "The labor which produces an insignificant poem would be enough to master a solid chapter of law" (European Graduate School, "Oliver Wendell Holmes"). In 1836 Holmes earned his M.D. from Harvard with his dissertation on acute pericarditis. However, despite each of Holmes' varying educational interests, his passion for writing never faded. Even at his busiest, Holmes somehow found time to write. The same year he earned his M.D., he also published his first collection of pieces, which he titled Poems. His popularity quickly grew, and as a result, people began asking him to write poems for specific occasions or events. As well as poems of tribute, Holmes also notoriously wrote poems about his observations of the world around him. Since he lived during the time of slavery and the Civil War, Holmes witnessed first hand slavery's many evils and the war it caused. These troubling observations led Holmes to side with the Northern cause as an abolitionist. Consequently, his strong political stances became evident through his writing. One of 
these poems, "The Flower of Liberty," describes the loyal and necessary patriotism found in the American flag. To him, the flag represented all the lives of the American people who sacrificed their lives for freedom, and this freedom was meant for everyone, even slaves.

\section{"The Flower of Liberty"}

WHAT flower is this that greets the morn, Its hues from Heaven so freshly born?

With burning star and flaming band It kindles all the sunset land:

Oh tell us what its name may be,-Is this the Flower of Liberty?

It is the banner of the free, The starry Flower of Liberty!

In savage Nature's far abode Its tender seed our fathers sowed; The storm-winds rocked its swelling bud, Its opening leaves were streaked with blood, Till lo! earth's tyrants shook to see The full-blown Flower of Liberty!

Then hail the banner of the free, The starry Flower of Liberty!

Behold its streaming rays unite, One mingling flood of braided light,-The red that fires the Southern rose, With spotless white from Northern snows, And, spangled o'er its azure, see The sister Stars of Liberty!

Then hail the banner of the free, The starry Flower of Liberty!

The blades of heroes fence it round, Where'er it springs is holy ground;

From tower and dome its glories spread; It waves where lonely sentries tread; It makes the land as ocean free, And plants an empire on the sea!

Then hail the banner of the free, The starry Flower of Liberty! 
Thy sacred leaves, fair Freedom's flower,

Shall ever float on dome and tower,

To all their heavenly colors true,

In blackening frost or crimson dew,--

And God love us as we love thee,

Thrice holy Flower of Liberty!

Then hail the banner of the free,

The starry FLOWER OF LIBERTY

\section{John Pierpont (1785-1866)}

Educator, attorney, minister, politician, and poet, John Pierpont is famous for boldly expressing his abolitionist beliefs through his work. Born into an illustrious family on April 6, 1785, in Litchfield, Connecticut, Pierpont was destined for a life of achievements. Among the first of these famous achievements was the success gained from his book of poetry, Airs of Palestine, published in 1816. Soon after its publication and his resulting new found literary acclaim, Pierpont wrote several school readers, such as The American First Class Book, and published multiple pieces of moral interest.

Whilst developing his respected authorial standing, he simultaneously earned esteem as a Unitarian pastor for Hollis Street Church in Boston and again as a seventy-six year old chaplain of the 22nd Massachusetts Infantry. Despite the frequent shifts in career, Pierpont held firm to his spiritual convictions and repeatedly shared his anti-slavery ideals, even when they were not well received. Recalling the uproar caused by Pierpont's Anti-Slavery Poems published in 1843, the author says: "Though some of my friends may grieve, and wish that I had been more prudent than to write the pieces that touch thus upon Human Liberty, and upon the outrageous wrongs that, in these days and in this our land, it has suffered, their grandchildren will thank me, and may be freer men for them" (Antislavery Literature Project). Though written in 1839, his poem titled “The Fugitive Slave's Apostrophe To The North Star" is exactly the type of 'piece' his 'friends [did] grieve.' Written from a slave's point of view, Pierpont describes the hope placed in the God who created the star "over Bethlehem's manger" and their pleas for delivery and his guidance. Soon after finishing this poem, Pierpont wrote its similarly titled antithesis "Slaveholder's Address To The North Star." Here, he describes the prideful thoughts and rationale of many slave owners, ultimately portraying them simply as ignorant fools.

\section{"The Fugitive Slave's Apostrophe To The North Star"}

STAR of the North! ${ }^{2}$ though night winds drift

The fleecy drapery of the sky

Between thy lamp and me, I lift,

Yea, lift with hope, my sleepless eye

To the blue heights wherein thou dwellest, And of a land of freedom tellest.

\footnotetext{
${ }^{2 " T h e ~ S t a r ~ o f ~ t h e ~ N o r t h " ~ i s ~ r e f e r r i n g ~ t o ~ t h e ~ s t a r ~ i n ~ M a t t h e w ~} 2$ of the Christian Bible, which led the wise men to Jesus ${ }^{3}$ This line parallels the slaves' secret Underground Railroad to the wise men's attempt at staying hidden by traveling only at night.
} 
Star of the North! while blazing day

Pours round me its full tide of light, And hides thy pale but faithful ray,

I, too, lie hid, and long for night: ${ }^{3}$

For night; - I dare not walk at noon,

Nor dare I trust the faithless moon,-

Nor faithless man, whose burning lust

For gold hath riveted my chain;

Nor other leader can I trust,

But thee, of even the starry train;

For, all the host around thee burning,

Like faithless man, keep turning, turning.

I may not follow where they go:

Star of the North, I look to thee

While on I press; for well I know

Thy light and truth shall set me free; -

Thy light, that no poor slave deceiveth;

Thy truth, that all my soul believeth.

They of the East beheld the star

That over Bethlehem's manager glowed;

With joy they hailed it from afar,

And followed where it marked the road,

Till, where its rays directly fell,

They found the Hope of Israel. ${ }^{4}$

Wise were the men who followed thus

The star that sets man free from sin!

Star of the North! thou art to us,-

Who're slaves because we wear a skin

Dark as is night's protecting wing,-

Thou art to us a holy thing.

And we are wise to follow thee!

I trust thy steady light alone:

Star of the North! thou seem'st to me

To burn before the Almighty's throne,

To guide me, through these forests dim

And vast, to liberty and HIM.

Thy beam is on the glassy breast

${ }^{4}$ The "Hope of Israel" refers to God's promise to the Israelites to deliver them from Egyptian enslavement in

Exodus 6:6. 
Of the still spring, upon whose brink

I lay my weary limbs to rest,

And bow my parching lips to drink.

Guide of the friendless negro's way,

I bless thee for this quiet ray!

In the dark top of southern pines

I nestled, when the driver's horn

Called to the field, in lengthening lines, My fellows at the break of morn.

And there I lay, till thy sweet face

Looked in upon "my hiding-place."

The tangled cane-brake,- - where I crept

For shelter from the heat of noon,

And where, while others toiled, I slept

Till wakened by the rising moon,-

As its stalks felt the night wind free,

Gave me to catch a glimpse of thee.

Star of the North! in bright array

The constellations round thee sweep,

Each holding on its nightly way,

Rising, or sinking in the deep,

And, as it hangs in mid-heaven flaming,

The homage of some nation claiming.

This nation to the Eagle cowers;

Fit ensign! she's a bird of spoil;

Like worships like! for each devours

The earnings of another's toil.

I've felt her talons and her beak,

And now the gentler Lion seek.

The Lion at the Virgin's feet

Crouches, and lays his mighty paw

Into her lap! — an emblem meet

Of England's Queen and English law:-

Queen, that hath made her Islands free!

Law, that holds out its shield to me!

Star of the North! upon that shield

Thou shinest!_ O, forever shine! 
The negro from the cotton-field

Shall then beneath its orb recline,

And feed the Lion couched before it,

Nor heed the Eagle screaming o'er it!

\section{"The Slaveholder's Address To The North Star"}

STAR of the North, thou art not bigger

Than is the diamond in my ring;

Yet every black, star-gazing nigger

Stares at thee, as at some great thing!

Yes, gazes at thee, till the lazy

And thankless rascal is half crazy.

Some Quaker scoundrel must have told 'em

That, if they take their flight toward thee,

They'd get where 'massa' cannot hold 'em;

And, therefore, to the North they flee.

Fools! to be led off, where they can't earn

Their living, by thy lying lantern.

Thou'rt a cold water star, I reckon,

Although I've never seen thee, yet,

When to the bath thy sisters beckon,

Get even thy golden sandals wet;

Nor in the wave have known thee dip,

In our hot nights, thy finger's tip.

If thou wouldst, nightly, leave the pole,

To enjoy a regular ablution

In the North Sea, or Symmes's hole, ${ }^{5}$

Our 'Patriarchal Institution,'

From which thou findest many a ransom,

Would, doubtless, give thee something handsome.

Although thou 'rt a cold water star,

As I have said, I think, already,

Thou 'rt hailed, by many a tipsy tar,

Who likes thee just because thou 'rt steady,

And hold'st the candle for the rover,

When he is more than 'half seas over.' 
But, while Ham's ${ }^{6}$ seed, our land to bless,

'Increase and multiply'7 like rabbits,

We like thee, Yankee Star, the less,

For thy bright eye, and steady habits.

Pray waltz with Venus, star of love,

Or take a bout with reeling Jove.

Thou art an abolition star,

And to my wench wilt be of use, if her

Dark eye should find thee, ere the car

Of our true old slave-catcher, 'Lucifer,

Star of the morning, upward rolls,

And, with its light, puts out the pole's.

On our field hands thou lookest, too -

A sort of nightly overseer-

Canst find no other work to do?

I tell thee, thou'rt not wanted here;

So, pray, shine only on the oceans,

Thou number one of 'Northern notions.'

Yes, northern notions, — northern lights!

As hates the devil holy water,

So hate I all that Rogers writes,

Or Weld, that married Grimkè's daughter:-

So hate I all these northern curses,

From Birney's prose to Whittier's verses.

'Put out the light!' exclaimed the Moor -

I think they call his name Othello -

When opening his wife's chamber door

To cut her throat - the princely fellow!

Noblest of all the nigger nation!

File leader in amalgamation!

'Put out the light!' and so say I.

Could 'I quench thee, thou flaming minister,'

No longer, in the northern sky,

Should blaze thy beacon-fire so sinister.

North Star, thy light's unwelcome - very -

We'll vote thee 'an incendiary.' 
And, to our 'natural allies' -

Our veteran Kinderhook Invincibles,

Who do our bidding, in the guise

Of 'northern men, with southern principles, '-

Men who have faces firm as dough,

And, as we set their noses, go -

To these, we'll get some scribe to write,

And tell them not to let thee shine -

Excepting of a cloudy night -

Any where, south of Dixon's line.

If, beyond that, thou shin'st, an inch

We'll have thee up before Judge Lynch: ${ }^{8}$ -

And when, thou abolition star,

Who preachest freedom, in all weathers,

Thou hast got on a coat of tar,

And, over that, a cloak of feathers,

That thou art 'fixed' shall none deny,

If there's a fixed star in the sky.

\section{William Gillmore Simms (1806-1870)}

By the age of eight, renowned author and historian William Gilmore Simms had already written his first poem. Best known for his political writings and pro-slavery arguments, famous poet Edgar Allen Poe described Simms as "the best novelist, which this country has, on the whole, produced." Born on April 17, 1806, in Charleston, South Carolina, Simms would grow up to be a prominent voice of antebellum Southern Literature. Although he dedicated most of his life to documenting the culture and history of his beloved South, at age eighteen Simms enrolled in law school. After passing the bar exam in 1827, he began to practice in his hometown of Charleston. However, soon thereafter Simms realized the irritating and unavoidable facets of practicing law and consequently deserted his career to focus on both his love for literature and the southern half of the United States. Unsurprisingly, since those were his two greatest passions, nearly all of his writings have Southern influence or themes. His book The Sword and the Distaff is among his most famous pieces, and stems from his clear opposition to Harriet Beecher Stowe's widespread antislavery novel, Uncle Tom's Cabin. In addition to his famous novels, however, Simms also published works of poetry. In his poem "Billows," Simms briefly describes only part of his argument for slavery, which essentially stated that slaves happily and sometimes even willingly served their owners because of their newfound purpose for their otherwise useless lives. Simms also wrote the poem "Yes, Lone Where My Bosom," which portrays a conversation between a Southerner doubting his faith and the God causing his doubt.

\section{"Billows"}

Gently, with sweet commotion,

${ }^{8}$ Lynching is the act of murdering someone, usually by hanging, which predominately happened to slaves and post-antebellum freed blacks. 
Sweeping the shore,

Billows that break from ocean,

Rush to our feet;

Slaves that, with fond devotion,

Prone to adore,

Seek not to stint with measure

Service that's meet;--

Bearing their liquid treasure,

Flinging it round,

Shouting the while the pleasure

True service knows,

Then as if bless'd with leisure,

Flung on the yellow ground

Taking repose!

"Yes, Lone Were My Bosom"

Yes, lone were my bosom if liken'd to thine,

And base were my soul if it knelt at thy shrine;

And the heaven we worship were false if it be

More true to the spoiler than thou wert to me.

If the hope that has cheer'd me through danger and death,

Be as easily lost as its owner's frail breath,

Then 'twere meet that my heart in its conflict should fly,

To the succor of him who decrees it to die.

If my hope of the future, as they tell me be vain,

Thy lures shall not win me to trust it again;

And the evening of life were but anguish to me,

Did I deem its sad sunlight vouchsafed me by thee.

Thou mayst rule o'er the slaves whom thy fortune has made;

I am none, and by me thou canst ne'er be betray'd:

I call for no curse on thy head but the one,

To trust with my trust, and, like me, be undone.

\section{Conclusion}

President Abraham Lincoln said it best with his foreboding pre-Civil War sentiment that "a house divided against itself cannot stand." As shown through these selected poems, the divisive issue of slavery drove a nearly catastrophic wedge through the American people whether it is politically or poetically. Through the poems' implicit tropes and explicit opinions, one begins to understand the sheer magnitude and polarizing nature of slavery, and also understand why the legacy of slavery persists today. 


\section{WORKs Cited}

Antislavery Literature Project. "Antislavery Poems." Antislavery Literature. Antislavery Literature Project, 2014. Web. 8 May 2014.

"Biographical Notes." American Poetry: The 19th Century. New York: First Library of America, 1993. 906. Print.

Cox, Rob S. “Finding Aid for John Pierpont Papers, 1854-1861.” William L. Clements Library Manuscripts Division Finding Aids. University of Michigan Digital Library, n.d. Web. 8 May 2014.

European Graduate School. "Henry Wadsworth Longfellow - Biography." Henry Wadsworth Longfellow. The European Graduate School: Graduate and Postgraduate Studies, n.d. Web. 7 May 2014.

---. “Oliver Wendell Holmes Sr - Biography." Oliver Wendell Holmes Sr. The European Graduate School: Graduate and Postgraduate Studies, n.d. Web. 8 May 2014.

Fenster, J.M. “Power Struggle." Ether Day: The Strange Tale of America's Greatest Medical Discovery and the Haunted Men Who Made It. New York: HarperCollins, 2001. 106-16. Print.

Halley, Edmond. An Account of the cause of the Change of the Variation of the Magnetic Needle; with an Hypothesis of the Structure of the Internal Parts of the Earth. Royal Society of London, 1692.563578. Print.

Holmes, Oliver Wendell. “The Flower of Liberty.” The Atlantic. Atlantic Media Company, n.d. Web. 8 May 2014.

The Holy Bible, King James Version. New York: American Bible Society, 1999. Print.

Maine Historical Society. Henry Wadsworth Longfellow. Maine Historical Society, n.d. Web. 8 May 2014.

McPherson, James. "A Brief Overview of the American Civil War." Council on Foreign Relations. Civil War Trust, n.d. Web. 7 May 2014.

Simms, William Gilmore. "Billows." Poems: Descriptive, Dramatic, Legendary and Contemplative. Vol. II. John Russell, 1853. 147. Documenting the American South. Electronic Edition. Web. 18 Mar. 2015.

---. “Yes, Lone Were My Bosom.” Poems: Descriptive, Dramatic, Legendary and Contemplative. Vol. II. 230.

Small, Miriam Rossiter. Oliver Wendell Homes. New York: Twayne Publishers, 1962. Print.

Wagenknecht, Edward. Henry Wadsworth Longfellow: Portrait of an American Humanist. Oxford University Press, 1966. Google Books. Web. 8 May 2014.

University Library. “William Gilmore Simms, 1806-1870.” Documenting the American South. University of North Carolina Press, 2004. Web. 8 May 2014. 